\title{
33. DATA REPORT: OEDOMETER AND TRIAXIAL TESTS OF SEDIMENT FROM THE CHILE TRIPLE JUNCTION ${ }^{1}$
}

\author{
V. Feeser ${ }^{2}$ and W. Brückmann ${ }^{3}$
}

\section{INTRODUCTION}

Deep-sea sediments deposited at or near an actively spreading mid-ocean ridge experience a distinctly different thermal history than sediments deposited in other marine geotectonic settings. For sediments of a given age the impact of high heat flow decreases with increasing distance from the ridge. This simple relation is superimposed in the active spreading ridge along the margin of Southern Chile-the Chile Triple Junction-by the process of sediment accretion. Both processes, heat flow and lateral thrusting, strongly modify the mechanical behavior of sediment accreted.

The original intent was to study the mechanical state of accreted sediment recovered during Ocean Drilling Program (ODP) Leg 141, both unaltered and altered diagenetically by hydrothermal fluids, to differentiate the effects of thermal and mechanical diagenesis. The research program included high-pressure oedometer as well as triaxial testing to quantify the relative importance of both diagenetic processes for shear strength and consolidation behavior.

Unfortunately, whole-round core samples available from Leg 141 appeared to be inadequately preserved and only a limited number of specimens could be used for mechanical testing. Therefore, most of the pre-cruise goals could not be attained. This paper reports the results of oedometer as well triaxial tests obtained from a restricted testing program.

\section{MATERIAL}

Drilling at Site 861 recovered hemipelagic sediments from the middle trench slope of the Chile Trench comprising mostly early Pliocene to Pleistocene clayey silts and silty clays. Site 863 is located at the base of the trench slope of the Chile Trench. Here the accretionary prism is underlain by the axial zone of the Chile Ridge. With the toe of the accretionary wedge emplaced on the rift zone, hydrothermal effluents from the ridge can penetrate accreted sediment and modify the fluid discharge system.

Five whole-round core samples were taken during Leg 141 at each site, at depths ranging from 18 to $660 \mathrm{mbsf}$, for shore-based testing. A compilation of all sample data appears in Table 1.

Samples from both sites were found to be highly disturbed, as evidenced by numerous penetrative cracks. The overall abundance of dissecting cracks increased with decreasing plasticity of the individual samples. Semisolid and solid samples were thoroughly broken into numerous fragments too small to be used in our testing equipment. Only three whole-round core samples from Site 861 and two from Site 863 were found to be suitable for mechanical testing. Preparation of test specimens was extremely difficult. In a number of

'Lewis, S.D., Behrmann, J.H., Musgrave, R.J., and Cande, S.C. (Eds.), 1995. Proc. ODP, Sci. Results, 141: College Station, TX (Ocean Drilling Program).

${ }^{2}$ Geologisch-Paläontologisches Institut der Universităt Kiel, Olshausenstraße 40-60, D-24098 Kiel, Federal Republic of Germany.

${ }^{3}$ GEOMAR, Research Center for Marine Geosciences, Wischhofstraße 1-3, D-24148 Kiel. Federal Republic of Germany. cases small chips broke off the edges of the specimen. In some instances, when testing conditions permitted, smaller chips were carefully placed back into their original position.

The reasons for the poor sample quality could not unambiguously be identified. It was observed that the whole-round core samples with plastic consistency that retained a cylindrical form did not completely fill the liner. Judging from the state of the end caps and the quality of the applied wax sealing it seems unlikely that any post-cruise desiccation and shrinking has affected the samples. Handling of the wholeround cores during and immediately after sampling seems to be the most likely reason for the observed effects of sample deterioration. Because of the presence of a circular void space around whole-round cores many samples experienced significant relaxation normal to the core axis, evidenced by numerous cracks oriented parallel to the core axis. A similar effect can be observed in the vertical direction. This is due to the fact that the end caps that were used as seals are too weak and deformable to impede relaxation in axial direction.

The nature and orientation of torsion and shear fractures in the semisolid and solid samples indicates that they originate in processes related to drilling and sampling. Additional mechanical disturbance during sample transport may have had an impact as well. Although it is not responsible for the generation of specific types of discontinuities, it did probably enhance previously formed ones, further weakening the structural framework of the samples.

\section{METHODS}

\section{Oedometer Tests}

The tests were performed using a fixed-ring oedometer with drainage at the bottom and top of the test specimen. Specimens were $31 \mathrm{~mm}$ in diameter and $16 \mathrm{~mm}$ in height. The loading of the specimen was applied through a mechanical lever arm capable of a vertical effective stress $\sigma^{\prime} 1$ of up to $10 \mathrm{MPa}$ (effective stresses, equal to the total stress $\sigma$ minus the pore pressure $u$, are identified by a prime [']). The settlement of the test specimen was measured with an electrical displacement transducer. The specimen installed in the apparatus was kept under water not until after the calculated in-situ overburden stress $\sigma_{\mathrm{v} \text { act }}^{\prime}$ was applied. The testing procedure followed the IL EOP-method (Mesri and Choi, 1985), where the test specimen is incrementally loaded just at the $e$ nd of primary consolidation of each loading step. For a given loading step the end of primary consolidation, where the excess pore pressure induced by loading is dispelled, is determined by using the square-root-of-time method proposed by Taylor (1942).

Test specimens were cut both parallel and normal to the core axis to observe the results of directional consolidation.

Test parameters are obtained as follows:

\section{Axial strain:}

$$
\varepsilon_{1}=\frac{\Delta H}{H_{0}}
$$

where $\Delta H$ is the settlement and $H_{0}$ the initial height of the specimen. 
Table 1. List of samples.

\begin{tabular}{|c|c|c|c|c|c|c|}
\hline \multicolumn{3}{|c|}{ Lithostratigraphy } & \multicolumn{4}{|c|}{ Sample } \\
\hline Unit & Age & Lithology & $\begin{array}{l}\text { Core, section. } \\
\text { interval }(\mathrm{cm})\end{array}$ & $\begin{array}{l}\text { Depth } \\
\text { (mbsf) }\end{array}$ & Consistency & Quality \\
\hline IIA & late Pleistocene to late Pliocene & Silty sand to clayey silt & $7 \mathrm{H}-5,135-150$ & 57.85 & Plastic & +- \\
\hline IIB & late Pliocene & Sandy silt & $40 \times-5.29-44$ & 339.27 & Semi-solid to solid & +- \\
\hline $\begin{array}{l}\text { IA } \\
\text { IB }\end{array}$ & late Pliocene & $\begin{array}{l}\text { Silty clay and clayey silt. olive gray } \\
\text { to greenish gray }\end{array}$ & $\begin{array}{l}141-863 \mathrm{~A}- \\
3 \mathrm{H}-4.135-150 \\
7 \mathrm{X}-2.135-150\end{array}$ & $\begin{array}{l}23.95 \\
58.95\end{array}$ & $\begin{array}{l}\text { Lowly plastic } \\
\text { Lowly plastic }\end{array}$ & + \\
\hline $\begin{array}{l}\text { IIB } \\
\text { IIC }\end{array}$ & & $\begin{array}{l}\text { Sandy and clayey silt, olive gray } \\
\text { Sandy silty claystone, olive } \\
\text { black to olive gray }\end{array}$ & $\begin{array}{l}141-86.3 \mathrm{~B}- \\
4 \mathrm{X}-4.135-150 \\
23 \mathrm{R}-1.135-150 \\
40 \mathrm{R}-3.92-107\end{array}$ & $\begin{array}{l}331.75 \\
493.75 \\
659.52\end{array}$ & $\begin{array}{l}\text { Plastic-solid alternating } \\
\text { Solid } \\
\text { Solid }\end{array}$ & 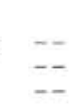 \\
\hline
\end{tabular}

$++=$ fully preserved. without any disturbance

$+=$ mostly preserved. partially cracked

$+-=$ noncontinuously cracked. core shape preserved

$-=$ continuously cracked, core shape preserved

$--=$ totally fragmented, core shape not preserved

Void ratio (defined as the ratio of the volume of voids to the volume of solids) during an oedometer test equals:

$$
e=e_{0}-\varepsilon_{1}\left(e_{0}+1\right),
$$

with $e_{0}$ the initial void ratio. If sediments are in a normally consolidated state (NC) the void ratio will be a linear function of the logarithm of the effective stress $\sigma_{1}^{\prime}$.

Oedometer modulus (defined as the slope of the $\varepsilon_{1}$ vs. $\sigma^{\prime}$, curve):

$$
M=\frac{d \sigma_{1}^{\prime}}{d \varepsilon_{1}} \approx \frac{\Delta \sigma_{1}^{\prime}}{\Delta \varepsilon_{1}}
$$

represents the sediment stiffness under geostatic conditions. In the case of normal consolidation (NC) sediment show a linear relationship between modulus $M$ and the effective stress $\sigma_{1}^{\prime}$.

\section{Compression index:}

$$
C_{c}=-\frac{\Delta e}{\Delta\left(\ln \sigma^{\prime}{ }_{I N C}\right)},
$$

is a measure for the sediment compressibility in the normally consolidated state $(\mathrm{NC})$ and the

\section{Swelling index:}

$$
C_{s}=-\frac{\Delta e}{\Delta\left(\ln \sigma_{1 O C}^{\prime}\right)},
$$

for the swelling potential during unloading in the overconsolidated state (OC).

\section{Triaxial Tests}

For shear-strength testing, a triaxial device of the type developed at the Institute for Soil Mechanics at Karlsruhe University was used (Topolnicki, 1987; Feeser et al., 1993). This device complies with the standards according to the suggestions of Berre (1985). Test specimens with an initial height $H_{0}=40 \mathrm{~mm}$ and initial diameter $D_{0}=40$ $\mathrm{mm}$ were used (DIN 18 137, 1990). This practice requires polished loading platens with good lubrication. Two latex membranes were placed around the specimen with lubrication between them. As in the oedometer testing the cylindrical specimens for triaxial testing were cut parallel as well as normal to the core axis.
Application of an initial pore water pressure (backpressure) prior to the reconsolidation ensured water saturation of the pore space of the specimen. The reconsolidation was performed isotropically up to or slightly above the calculated in-situ overburden stress $\sigma_{\text {vact }}^{\prime}$. After that, the specimens were loaded undrained to failure (CIUC-test: consolidated isotropically, undrained compression). Excess pore pressure $u$ was measured.

The test parameters are obtained as follows:

\section{Mean effective stress:}

$$
s^{\prime}=\frac{\sigma_{1}^{\prime}+\sigma_{3}^{\prime}}{2}
$$

and deviator stress

$$
t=\frac{\sigma_{1}-\sigma_{3}}{2},
$$

where $\sigma_{1}$ denotes the axial and $\sigma_{3}$ the radial stress measured during testing.

\section{Axial strain:}

$$
\varepsilon_{1}=\frac{\Delta H}{H_{0}},
$$

where $\Delta H$ is the axial displacement and $H_{0}$ the initial height of the specimen.

Initial Young's modulus (defined as the slope of the initial branch of the $t$ vs. $\varepsilon_{1}$ plot):

$$
E_{0}=\frac{d t}{d \varepsilon_{1}} \approx \frac{\Delta t}{\Delta \varepsilon_{1}}
$$

is a measure of sediment resistance against shear deformation.

Failure criterion, defined as the maximum of deviator stress in the $t$ vs. $\varepsilon_{1}$ plot:

$$
\frac{\sigma_{1}^{\prime}-\sigma_{3}^{\prime}}{2} \Rightarrow \max
$$

or as the maximum of effective stress ratio in the $\sigma_{1}^{\prime} / \sigma_{3}^{\prime}$ vs. $\varepsilon_{1}$ plot,

$$
\frac{\sigma_{1}^{\prime}}{\sigma_{3}^{\prime}} \Rightarrow \max \text {. }
$$


Table 2. Testing program.

\begin{tabular}{|c|c|c|c|c|c|c|c|}
\hline \multirow[b]{2}{*}{$\begin{array}{l}\text { Core, section. } \\
\text { interval }(\mathrm{cm})\end{array}$} & \multirow[b]{2}{*}{$\begin{array}{l}\text { Depth } \\
\text { (mbsf) }\end{array}$} & \multirow{2}{*}{$\begin{array}{c}\text { Calculated } \\
\text { vertical } \\
\text { overburden stress } \\
(\mathrm{kPa})\end{array}$} & \multirow[b]{2}{*}{$\begin{array}{c}\text { Sample orientation } \\
\text { (horizontal or } \\
\text { vertical) }\end{array}$} & \multicolumn{3}{|c|}{ Triaxial tests } & \multirow{2}{*}{$\begin{array}{c}\text { Oedometer tests } \\
\begin{array}{c}\text { Maximal } \\
\text { loading } \\
\text { (MPa) }\end{array}\end{array}$} \\
\hline & & & & $\begin{array}{l}\text { Reconsolidation } \\
\text { stress } \\
(\mathrm{kPa})\end{array}$ & $\begin{array}{c}\text { Back pressure } \\
(\mathrm{kPa})\end{array}$ & $\begin{array}{l}\text { Strain rate } \\
(\mathrm{mm} / \mathrm{min})\end{array}$ & \\
\hline \multicolumn{8}{|l|}{$141-86 \mid \mathrm{C}$} \\
\hline \multirow[t]{2}{*}{$3 \mathrm{H}-4,135-150$} & 18.35 & 146.8 & V & 150 & 750 & 0.02 & 10.6 \\
\hline & & & $\mathrm{H}$ & 150 & 750 & 0.02 & 4.4 \\
\hline \multirow{2}{*}{$7 \mathrm{H}-5,135-150$} & 57.85 & 484.0 & V & 500 & 750 & 0.02 & 4.4 \\
\hline & & & $\mathrm{H}$ & & & & 3.4 \\
\hline \multirow{2}{*}{$22 X-2.135-150$} & 182.75 & 1684.5 & V & 1700 & 750 & 0.02 & 10.6 \\
\hline & & & $\mathrm{H}$ & 1700 & 750 & 0.02 & \\
\hline \multirow{3}{*}{$\begin{array}{l}14 \mathrm{I}-863 \mathrm{~A}- \\
3 \mathrm{H}-4.135-150\end{array}$} & & & & & & & \\
\hline & 23.95 & 232.8 & V & 250 & 750 & 0.02 & 10.6 \\
\hline & & & $\mathrm{H}$ & 250 & 750 & 0.02 & 10.6 \\
\hline \multirow[t]{2}{*}{$7 X-2.135-150$} & 58.95 & 599.5 & V & 600 & 750 & 0.02 & 10.6 \\
\hline & & & $\mathrm{H}$ & 600 & 750 & 0.02 & 10.6 \\
\hline
\end{tabular}

For the evaluation of individual tests the appropriate criterion was used.

Shear strength parameters are approximately derived from a single triaxial test using $t$ vs. $s^{\prime}$ stress path plot. The tangent to the branch of $t \mathrm{vs}$. $s^{\prime}$ curve beyond the point representing the failure criterion is supposed to be the failure-line (failure envelope). The relationship between the inclination of the failure-line $\Phi^{\prime}$ and the angle of internal friction $\phi^{\prime}$ is given by

$$
\sin \phi^{\prime}=\tan \Phi^{\prime} .
$$

If the failure-line intercepts the $t$ axis, denoted by $t_{0}$, the value of the effective cohesion $c^{\prime}$ is given by

$$
c^{\prime}=\frac{t_{0}}{\cos \phi^{\prime}} .
$$

The parameter cohesion indicates that the sediment has experienced overconsolidation or chemical diagenesis. Normally consolidated sediments do not show significant cohesion.

\section{Testing Program}

An overview of the oedometer and triaxial testing program is given in Table 2. Table 3 summarizes the symbols for variables used in this paper as outlined by Lambe and Whitman (1979). To mark the individual tests for presentation, a combination of an abbreviation of the test type $(\mathrm{OE}=$ oedometer, $\mathrm{TR}=$ triaxial $)$, the numerical ODP sample identifier, and an extension denoting the orientation of the axis of the test specimen ( $\mathrm{V}=$ vertical, $\mathrm{H}=$ horizontal) is used.

\section{RESULTS}

\section{Oedometer Tests}

The results are presented as semilogarithmic plots of void ratio $e$ vs. the natural logarithm of the vertical effective stress $\sigma_{1}^{\prime}$ and as plots of oedometer modulus $M$ vs. vertical effective stress $\sigma_{1}^{\prime}$ from samples of Site 861 (Fig. 1) and Site 863 (Fig. 2). Table 4 contains the compression and swelling indices.

Site 861 results show in most cases curves with linear trends typical for normally consolidated sediments (Figs. 1A-D). Only sample OE 191-861C-22X-2, 135-150 (V) did not show normally consolidated behavior over the whole stress range tested (Fig. IE). The bended $\varepsilon_{1}-\ln \sigma_{1}^{\prime}$ curve pattern and position of the $M$ - $\sigma_{1}^{\prime}$ curve above the NC state-line describes a mechanical behavior typical for a high degree of overconsolidation. The transition from over- to normal consolidated behavior is located above $\sigma_{1}^{\prime}=10 \mathrm{MPa}$.

Overconsolidated behavior is expected from all samples at least in the stress range below the current overburden stress $\sigma_{v \text { act }}^{\prime}$. As most samples do not show this behavior, we conclude that this is a direct effect of the mechanical disturbance observed. Therefore, test results

\begin{tabular}{|c|c|c|}
\hline Symbol & Definition & Dimension \\
\hline$\sigma_{\text {, ast }}^{\prime}$ & Calculated in-situ overburden stress & $(\mathrm{kPa}, \mathrm{MPa})$ \\
\hline$\sigma_{1}^{\prime}$ & Effective vertical stress $>$ applied & (MPa) \\
\hline$\sigma^{\prime}$ & Effective horizontal stress $>$ in the tests & (MPa) \\
\hline$u$ & Pore pressure & (MPa) \\
\hline$\varepsilon_{1}$ & Vertical strain & - \\
\hline$e$ & Void ratio & - \\
\hline$e_{n}$ & Initial void ratio & - \\
\hline$C_{4}$ & Compression index & $\left(\mathrm{MPa}^{-1}\right)$ \\
\hline$C$ & Swelling index & $\left(\mathrm{MPa}^{-1}\right)$ \\
\hline M & Oedometer modulus & (MPa) \\
\hline$s^{\prime}$ & Mean effective stress (MIT-parameter) & (MPa) \\
\hline$t$ & Deviator stress (MIT-parameter) ${ }^{6}$ & (MPa) \\
\hline$\phi^{\prime}$ & Effective angle of internal friction & $\left({ }^{\circ}\right)$ \\
\hline$c^{\prime}$ & Effective cohesion & (kPa) \\
\hline$E_{i j}$ & Initial Young's modulus under shear deformation & (MPa) \\
\hline
\end{tabular}

Table 3. Definition of symbols.

Note: ${ }^{\text {p }}=$ Massachusetts Institute of Technology.

provide only limited clues to the true nature of the mechanical behavior of the samples tested.

The diagrams representing test results from Site 863 samples show with one exception (test OE 141-863 A-7X-2, 135-150 (H); Fig. 2D) the transition from over- to normal consolidated behavior (Figs. 2A-C). This is evidenced by the transition of a bended into a linear branch of the $\varepsilon_{1}-\ln \sigma_{1}^{\prime}$ curves and by the proximity of the $M-\sigma_{1}^{\prime}$ curves to the NC state-line. Steps in the $\varepsilon_{1}-\ln \sigma_{1}^{\prime}$ curves indicate structural break down typical for mechanically disturbed samples. Thus, these results also do not provide a complete picture of the mechanical properties of the Site 863 sediments.

Due to their limited validity test results can only be used in a qualitative comparison. A comparison of calculated compaction and swelling indices for all samples shows that the sediments of Site 861 obviously have a higher compressibility and a higher swelling tendency than the sediments from Site 863 (Table 4). As there are no clear trends observed in the calculated compression indices for vertical and horizontal samples it is not possible to identify a directional dependence of the compressibility. However, a weakly developed directional dependence can be seen in the swelling behavior: samples from both sites show a slightly higher swelling potential in vertical than in horizontal direction (Table 4).

\section{Triaxial Tests}

The results are presented as stress paths in the $t-s^{\prime}$ stress field (Lambe and Whitman, 1979) and deviator stress $t$, stress ratio $\sigma_{1}^{\prime} / \sigma_{3}^{\prime}$ respectively vs. axial strain $\varepsilon_{1}$. Site 861 data are given in Figure 3, and Site 863 data in Figure 4. The inferred angles of internal effective friction $\phi^{\prime}$, effective cohesion $c^{\prime}$, and the initial Young's modulus $\mathrm{E}_{0}$ are shown in Table 5. 

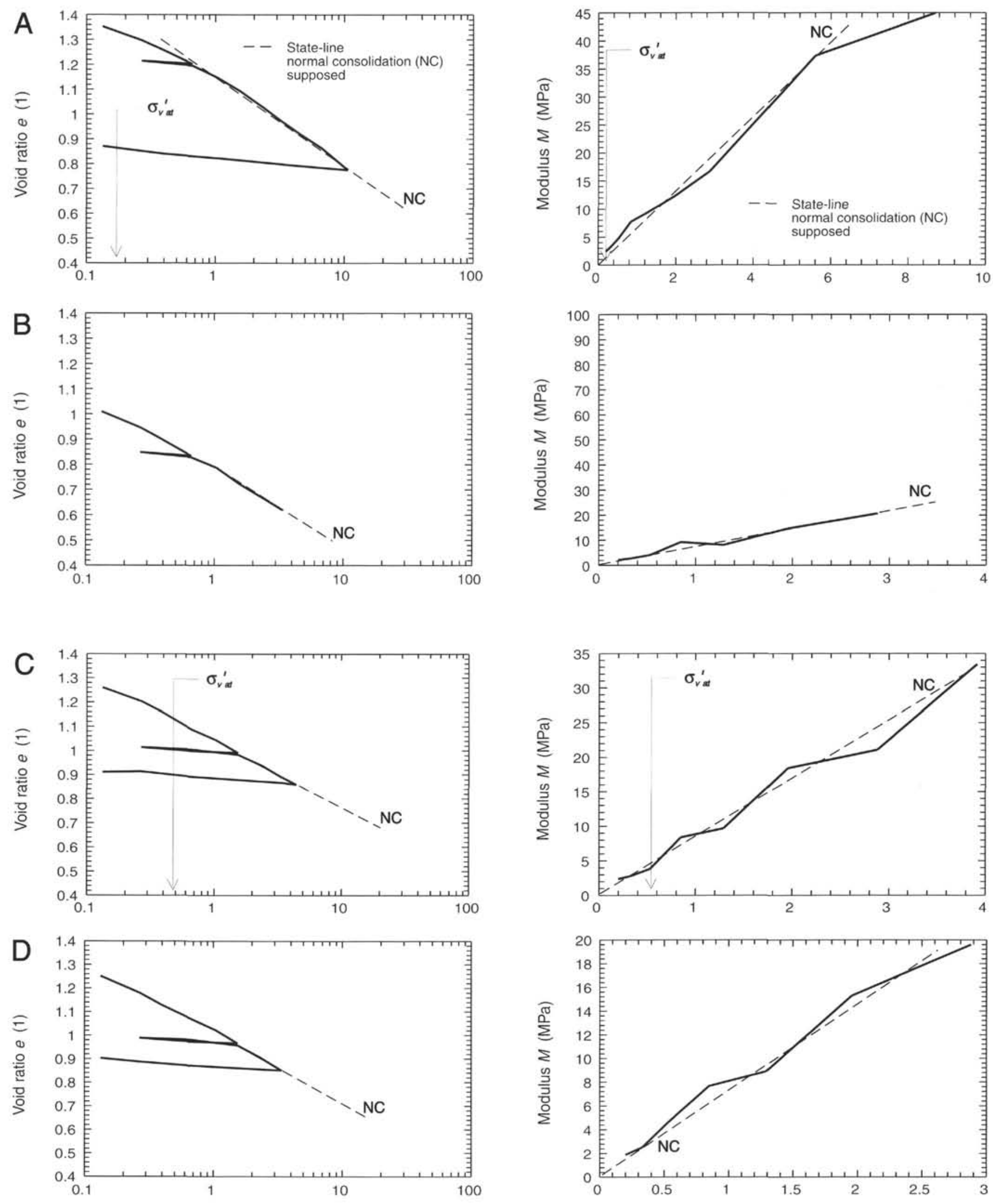

Effective vertical stress In $\sigma_{i}^{\prime}(\mathrm{MPa})$

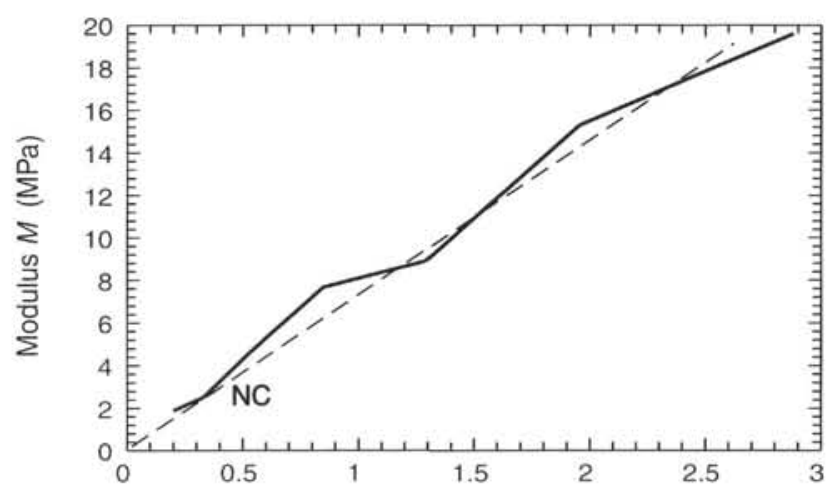

Figure 1. Results of oedometer tests. Compression plane: semilogarithmic plot of void ratio vs. vertical effective stress. Development of sediment stiffness: arithmetic plot of oedometer modulus vs. vertical effective stress. A. Sample 141-861C-3H-4, 135-150 cm (18.35 mbsf) vertically loaded in the test. B. Sample 141-861C-3H-4, $135-150 \mathrm{~cm}$ (18.35 mbsf) horizontally loaded in the test. C. Sample 141-861C-7H-5, 135-150 cm (57.85 mbsf) vertically loaded in the test. D. Sample $141-861$ C-7H-5, $135-150 \mathrm{~cm}$ ( $57.85 \mathrm{mbsf})$ horizontally loaded in the test. E. Sample $141-861 \mathrm{C}-22 \mathrm{X}-2,135-150 \mathrm{~cm}$ (182.75 mbsf) vertically loaded in the test. 


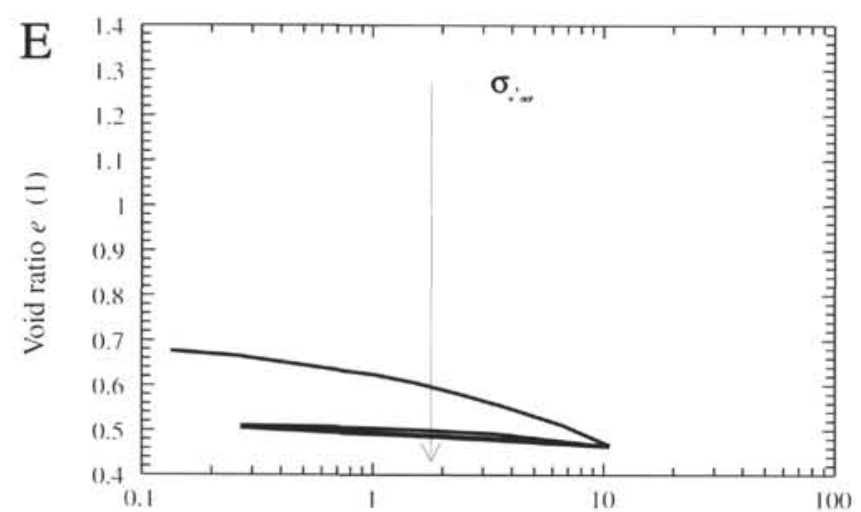

Effective vertical stress In $\sigma_{i}^{\prime}(\mathrm{MPa})$

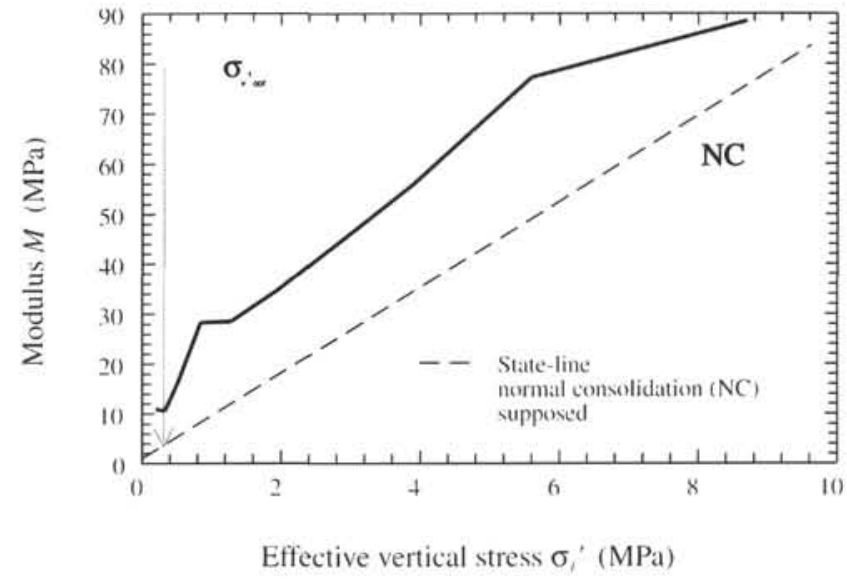

Effective vertical stress $\sigma_{i}^{\prime}(\mathrm{MPa})$

Figure 1 (continued).

Table 4. Oedometer tests: compression and swelling indices.

\begin{tabular}{|c|c|c|c|c|c|}
\hline \multirow[b]{2}{*}{ Test number } & & \multirow[b]{2}{*}{$\begin{array}{l}\text { Depth } \\
\text { (mbsf) }\end{array}$} & \multirow[b]{2}{*}{$\begin{array}{c}\text { Compression } \\
\text { index } C_{C} \\
\text { (NC-state) }\end{array}$} & \multicolumn{2}{|c|}{ Swelling index $C_{S}$} \\
\hline & & & & $\begin{array}{l}\text { Ist unloading } \\
\text { (OC state) }\end{array}$ & $\begin{array}{l}\text { 2nd unloading } \\
\text { (OC state) }\end{array}$ \\
\hline \multirow[t]{2}{*}{$\mathrm{OE} 861 \mathrm{C}-3 \mathrm{H}-4,135-150$} & (V) & 18.35 & 0.384 & 0.0327 & 0.0435 \\
\hline & (H) & & 0.316 & 0.0257 & - \\
\hline \multirow{2}{*}{ OE $861 \mathrm{C}-7 \mathrm{H}-5.135-150$} & (V) & 57.85 & 0.296 & 0.0306 & 0.0442 \\
\hline & (H) & & 0.330 & 0.0374 & 0.0323 \\
\hline OE $86 \mid C-22 X-2,135-150$ & (V) & 182.75 & $0.219^{*}$ & 0.0265 & 0.0255 \\
\hline \multirow[t]{2}{*}{$\mathrm{OE} 863 \mathrm{~A}-3 \mathrm{H}-4,135-150$} & (V) & 23.95 & 0.207 & 0.0119 & 0.0310 \\
\hline & (H) & & 0.213 & 0.0179 & 0.0262 \\
\hline \multirow[t]{2}{*}{ OE $863 \mathrm{~A}-7 \mathrm{X}-2.135-150$} & (V) & 58.95 & 0.234 & 0.0204 & 0.0340 \\
\hline & (H) & & 0.221 & 0.0408 & 0.0340 \\
\hline
\end{tabular}

Note: $*$ = normally consolidated state $(\mathrm{NC})$ not reached.

Table 5. Triaxial tests: shear parameter and initial Young's moduli.

\begin{tabular}{|c|c|c|c|c|c|c|}
\hline Test number & & $\begin{array}{l}\text { Depth } \\
\text { (mbsf) }\end{array}$ & $\begin{array}{l}\text { Radial confining } \\
\text { pressure } \sigma_{3} \\
\text { (kPa) }\end{array}$ & $\begin{array}{c}\text { Angle of internal } \\
\text { friction } \phi^{\prime} \\
\left({ }^{\circ}\right)\end{array}$ & $\begin{array}{c}\text { Effective cohesion } \\
\ell^{\prime}(\mathrm{kPa})\end{array}$ & $\begin{array}{l}\text { Initial Young's } \\
\text { modulus } E_{0} \\
\text { (MPa) }\end{array}$ \\
\hline \multirow[t]{2}{*}{ TR 86 IC $-3 \mathrm{H}-4.135-150$} & (V) & 18.35 & 150 & 25 & - & 4 \\
\hline & (H) & & 1.50 & 26 & - & 5 \\
\hline TR $861 \mathrm{C}-7 \mathrm{H}-5,135-150$ & (v) & 57.85 & 500 & 30 & - & 20 \\
\hline \multirow[t]{2}{*}{ TR $861 \mathrm{C}-22 \mathrm{X}-2.135-150$} & (V) & 182.75 & 1700 & 27 & - & 68 \\
\hline & (H) & & 1700 & 28 & - & 56 \\
\hline \multirow{2}{*}{ TR $863 \mathrm{~A}-3 \mathrm{H}-4,135-150$} & (V) & 23.95 & 250 & 35 & 12 & 15 \\
\hline & (H) & & 250 & 32 & 20 & 13 \\
\hline \multirow[t]{2}{*}{ TR $863 \mathrm{~A}-7 \mathrm{X}-2,135-150$} & (v) & 58.15 & 600 & 33 & 25 & 48 \\
\hline & (H) & & 600 & 35 & 29 & 41 \\
\hline
\end{tabular}

In accordance with trends seen in the OE samples, where samples from Site 863 show a weaker compaction and swelling tendency than those from Site 861, TR samples from Site 863 generally show higher shear strength than samples from Site 861 (Table 5). This is evidenced by higher angles of internal friction $\phi^{\prime}$ as well as by the presence of effective cohesion $c^{\prime}$ in Site 863 samples. Site 861 samples do not show cohesion in the observed stress range.

Based on our data from neither Site 861 nor Site 863 no significant anisotropy in shear strength of vertical and horizontal samples tested could be observed (Table 5). A different behavior is seen in the initial stiffness under shear deformation as illustrated by $t$ vs. $\varepsilon_{1}$ plots (Figs. 3 and 4). If described by the initial Young's modulus $E_{0}$ all samples tested (with the exception of near-surface Sample TR 141-861C-3H$4,135-150 \mathrm{~cm}$ ) show a higher degree of stiffness in vertical than in horizontal direction (Table 5). This anisotropic behavior is also expressed in $t-s^{\prime}$ stress paths (Figs. 3 and 4 ). While the stress paths of the samples vertically tested are moderately single-bent, which is typical for stiff sediment with a subordinate increase of pore pressure, the horizontal samples show double-bent stress paths that indicate a temporary increase in pore pressure induced by a lower sediment stiffness. However, the patterns of all stress paths obtained generally suggest shear properties as they are characteristic for overconsolidated behavior.

At least for Site 861 samples the features of overconsolidation in triaxial testing do not correspond with the normal consolidation behavior obtained in oedometer testing (i.e., the triaxial tests do not show such a clear influence of poor sample quality on the validity of test results as shown in the oedometer tests. Only the observed discontinuous trend of the $t-\varepsilon_{1}$ curves points to a possible mechanical disturbance of the tested samples: a steep initial slope, indicating high stiffness, is followed by pre-failure transition to a moderate slope, indicating lower stiffness which may be caused by a structural break down. 

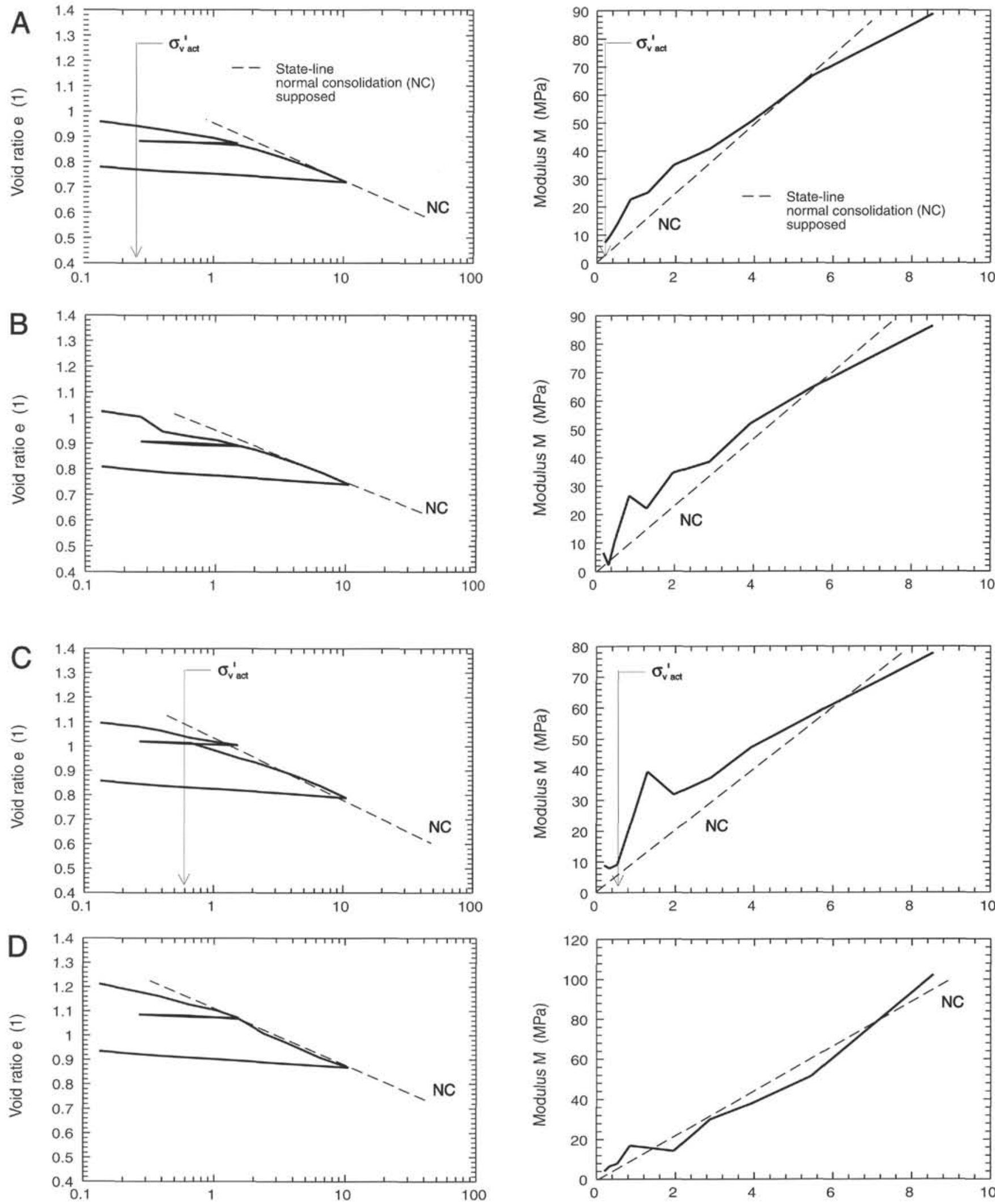

Effective vertical stress $\ln \sigma_{1}^{\prime}(\mathrm{MPa})$

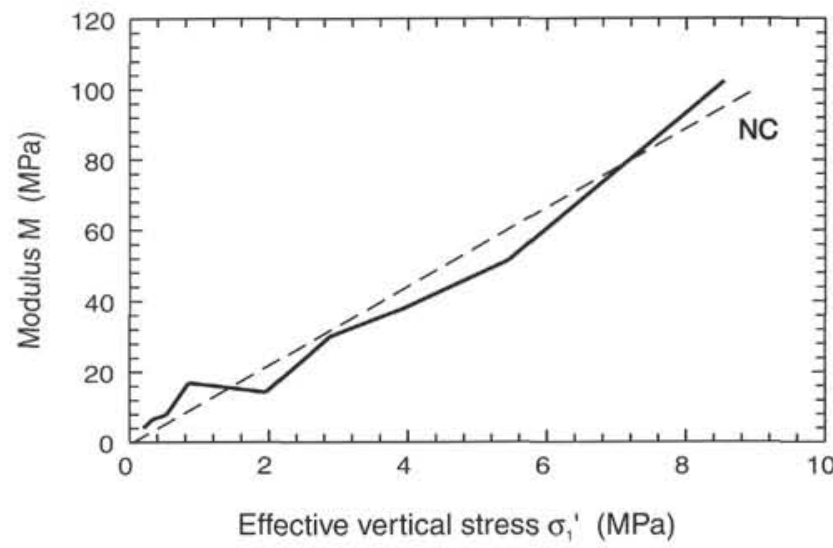

Figure 2. Results of oedometer tests. Compression plane: semilogarithmic plot of void ratio vs. vertical effective stress. Development of sediment stiffness: arithmetic plot of oedometer modulus vs. vertical effective stress. A. Sample $141-863 \mathrm{~A}-3 \mathrm{H}-4,135-150 \mathrm{~cm}(23.95 \mathrm{mbsf})$ vertically loaded in the test. B. Sample $141-863 \mathrm{~A}-3 \mathrm{H}-4,135-150 \mathrm{~cm}$ (23.95 mbsf) horizontally loaded in the test. C. Sample 141-863A-7X-2, 135-150 cm (58.95 mbsf) vertically loaded in the test. D. Sample 141-863A-7X-2, 135-150 cm (58.95 mbsf) horizontally loaded in the test. 


\section{CONCLUSIONS}

The limited set of tests - primarily because of the poor quality of the samples available - does not support a well-founded interpretation of the impact of thermally controlled diagenetic alteration on the mechanical behavior of sediment. As proposed earlier (Feeser et al., 1993), much more sophisticated methods are needed for sampling and conservation of drilled deep-sea sediments in order to solve mechanical soft rock questions.

From the results obtained, however, it is reasonable to suspect a diagenetic impact of hydrothermal fluids, which is evidenced in the compaction and swelling behavior as well as the shear strength properties. Additionally, all hydrothermally impacted samples from Site 863 show, regardless of the direction of their testing, 2-3 times higher initial stiffness under shear deformation compared to "nonimpacted" samples from Site 861, keeping in mind that increasing confining pressure is responsible for increasing stiffness.

Sediments overconsolidated in the vertical direction generally show a higher stiffness in the horizontal than in the vertical direction during triaxial compression in the overconsolidation state (Parry and Worth, 1981; Wood, 1990). Most of the samples tested here show typical stress path patterns of overconsolidated sediment. However, contrary to expected behavior, higher stiffness was measured in the vertical direction. This indicates, in accordance with earlier findings on sediment samples from the Nankai accretionary prism (Feeser et al., 1993), that the observed anisotropies in the swelling as well as in the shear strength and shear stiffness behavior are a direct result of the inverse in-situ stress state. This situation is typical under the conditions of large lateral thrusting during accretion in trench-forearc systems dominated by higher horizontal than vertical stresses.

\section{ACKNOWLEDGMENTS}

This study was financially supported by the Deutsche Forschungsgemeinschaft DFG. The tests were carried out at the Institute for Soil Mechanics at Karlsruhe University by E. Bösinger (Karlsruhe) and N.
Nutbohm (Kiel). T. Voss helped us with the preparation of the manuscript. The authors wish to thank everyone.

\section{REFERENCES $^{*}$}

Berre, T., 1985. Suggested International Code of Soil Engineering Practice for Triaxial Compression Tests: NGI (Oslo).

DIN 18 137, 1990. (German Standard) Testing Procedures and Apparatus: Triaxial test, Part 2: Berlin (Deutsches Institut für Normung).

Feeser, V., Moran, K., and Brückmann, W., 1993. Stress-regime-controlled yield and strength behavior of sediment from the frontal part of the Nankai accretionary prism. In Hill, I.A., Taira, A., Firth, J.V., et al., Proc. ODP, Sci. Results, 131: College Station, TX (Ocean Drilling Program), 261-273,

Lambe, T.W., and Whitman, R.V., 1979. Soil Mechanics (SI ed.): New York (Wiley).

Mesri, G., and Choi, Y.K., 1985. The uniqueness of the end-of-primary (EOP) void ratio-effective stress relationship. Proc. IX Int. Conf. Soil. Mech. Found. Eng., San Francisco (Vol. 2), 587-590.

Parry, R.H.G., and Worth, C.P., 1981. Shear stress-strain properties of soft clays. In Brand, E.W., and Brenner, R.P., Soft Clay Engineering: Amsterdam (Elsevier), 311-366.

Taylor, D.W., 1942. Fundamentals of Soil Mechanics: New York (Wiley), 229-239.

Topolnicki, M., 1987. Observed stress-strain behavior of remoulded saturated clay and examination of two constitutive models. Veroff. Inst. Bodenmech. Felsmech. Univ. Karlsruhe, H. 107.

Wood, D.M., 1990. Soil Behaviour and Critical State Soil Mechanics: Cambridge (Cambridge Univ. Press).

Abbreviations for names of organizations and publications in ODP reference lists follow the style given in Chemical Abstracts Service Source Index (published by American Chemical Society).

Date of initial receipt: 23 July 1993

Date of acceptance: 6 December 1993

Ms 141SR-041 

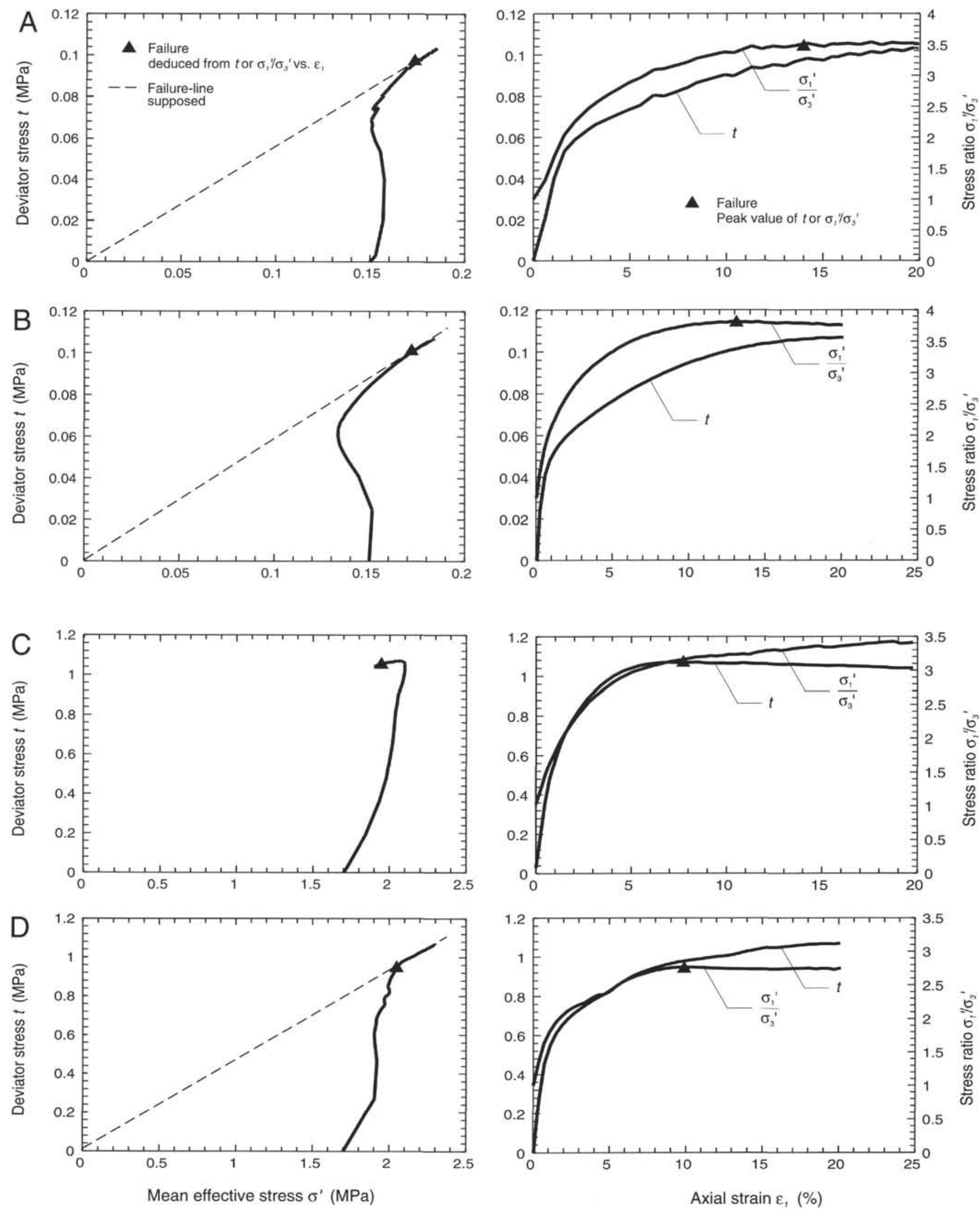

Figure 3. Results of triaxial tests (CIUC). Deviator stress vs. mean effective stress (MIT stress field). Deviator stress as well as stress ratio vs. axial strain. A. Sample 141-861C-3H-4, 135-150 cm (18.35 mbsf) vertically loaded in the test. B. Sample 141-861C-3H-4, 135-150 cm (18.35 mbsf) horizontally loaded in the test. C. Sample 141-861C-22X-2, 135-150 cm (182.75 mbsf) vertically loaded in the test. D. Sample 141-861C-22X-2, 135-150 cm (182.75 mbsf) horizontally loaded in the test. E. Sample 141-861C-7H-5, 135-150 cm (57.85 mbsf) vertically loaded in the test. 

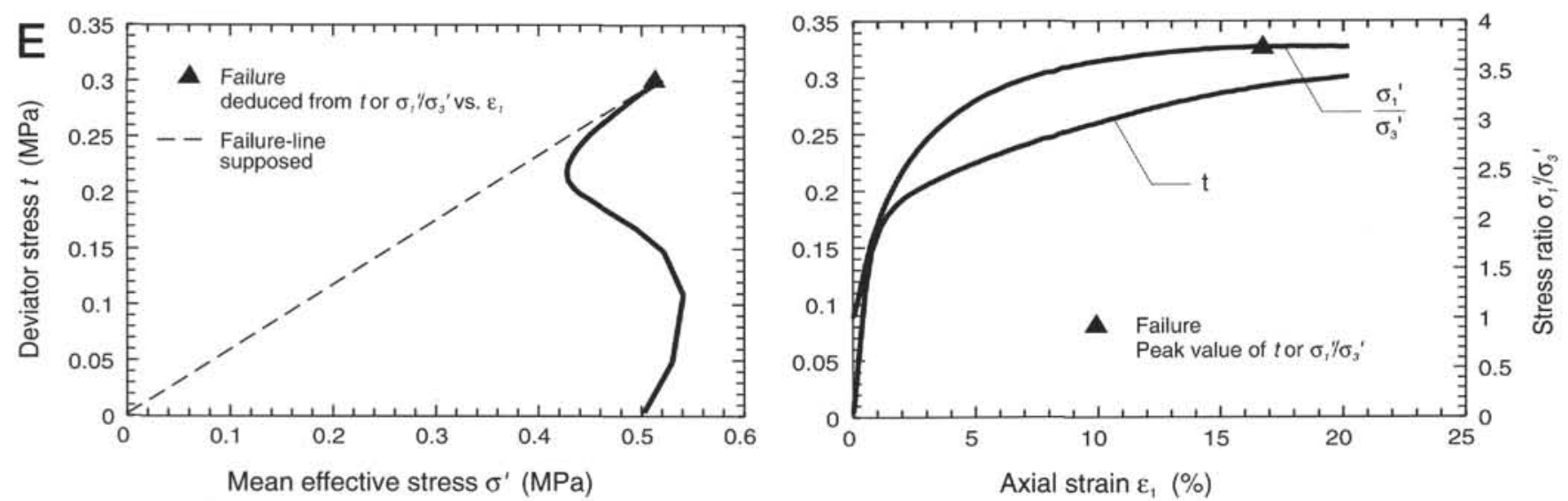

Figure 3 (continued). 

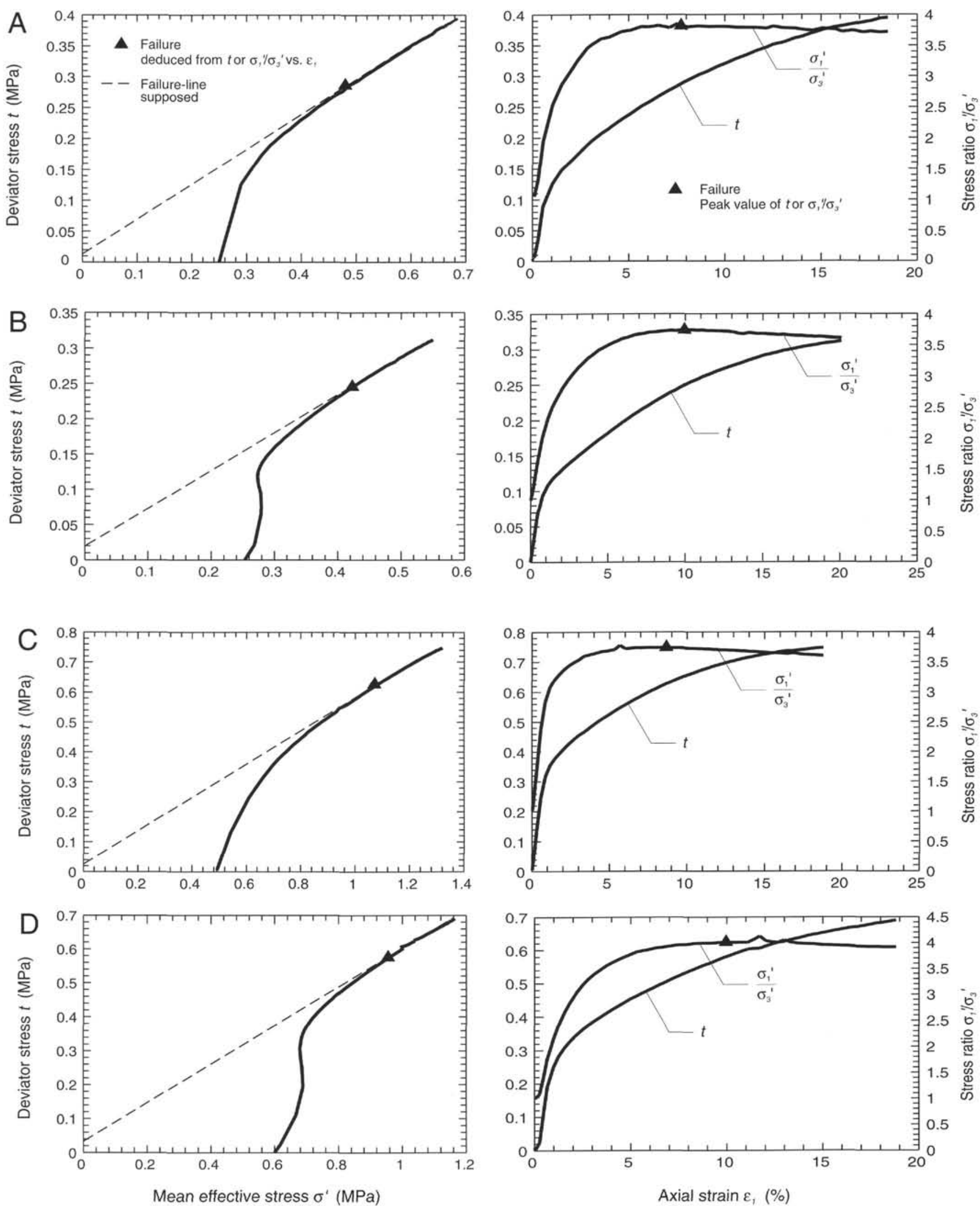

Figure 4. Results of triaxial tests (CIUC). Deviator stress vs. mean effective stress (MIT stress field). Deviator stress as well as stress ratio vs. axial strain. A. Sample 141-863A-3H-4, 135-150 cm (23.95 mbsf) vertically loaded in the test. B. Sample 141-863A-3H-4, $135-150 \mathrm{~cm}$ ( 23.95 mbsf) horizontally loaded in the test. C. Sample 141-863A-7X-2, 135-150 cm (58.95 mbsf) vertically loaded in the test. D. Sample 141-863A-7X-2, 135-150 cm (58.95 mbsf) horizontally loaded in the test. 